\title{
EDITORIAL
}

\section{Socratic Method of Teaching in Medical Education}

\author{
Rehan Ahmed Khan ${ }^{1}$ \\ 1 Editor in chief, Health Professions Educator Journal, Lahore, Pakistan.
}

doi: https://doi.org/10.53708/hpej.v4i1.1302

This is an Open Access article and is licensed under a creative commons attribution (4.0 international License).

Socrates (469-399BC) is regarded as the founder of Western philosophy. His method of teaching was based on a shared discourse between teachers and students. He would ask thought provoking questions from his students. This would result in motivating the students to think and generate debate. This was an iterative process and would continue till the answers to the questions were found or discussion was exhausted. This method is termed as Socratic method of teaching (Birnbache, 1999). It also involves the zone of proximal development and scaffolding as advocated by Vygotsky. Many teaching method, based on small group teaching such as problem-based learning, casebased learning, one minute preceptor rely on the philosophy of Socratic method.

Socratic method relies on getting the answers from the students rather than telling them the answers directly. Socrates in his sessions would pick students randomly and ask them a question. The student would either answer the question if $s /$ he knows it or would learn it from the discussion between her/his peers and the teachers.

This method of teaching is also known as Socratic debate and involves a helpful and accommodating argumentative dialogue that not only stimulates critical thinking but generate newer ideas. Through this method, though teacher aims that students learn the factual knowledge, but they put more emphasis on the use of this knowledge. In this method both teacher and students move the discussion forward through a process of questioning called Socratic questioning. It is opposite to the idea of the sage on the stage in the medical education in which teacher is the centre of focus. In Socratic style of questioning, the teacher acts ignorant and expects from the students to contribute to the discussion. These questions that are asked from the student can be concise and directed or open but with a purpose (Oh, 2005).

Correspondence:

Prof. Dr. Rehan Ahmed Khan,

Editor in chief, Health Professions Educator Journal, Lahore, Pakistan.

E-mail: surgeonrehan@gmail.com
In contrary to Socratic method, didactic teaching involves verbal delivery of facts in which the learner is inactive. This is purely instructor led and fails to gain attention of a student for longer duration (Zou et al., 2011). This method is mainly used in didactic lectures. Another method of teaching that is based on questioning that is employed in clinical teaching is called as 'Pimping'. This is aggressive form of Socratic questioning and should be discouraged (Oh \& Reamy, 2014). In this method, the senior clinician asks questions from interns or medical students that are intentionally unanswerable or are very difficult. This results in embarrassment or humiliation of the medical students and deter learning.

Socratic method of teaching has passed the test of time and is still successful after 2500 years. When used in its true essence and spirit, it promotes active learning through promotion of critical and logical thinking.

\section{REFERENCES}

Birnbache, D. (1999). The Socratic method in teaching medical ethics: potentials and limitations. Medicine, Health Care and Philosophy, 2(3), 219-224.

Oh, R. C. (2005). The Socratic method in medicine-the labor of delivering medical truths. Family medicine-kansas city-, 37(8), 537 .

Oh, R. C., \& Reamy, B. V. (2014). The Socratic method and pimping: optimizing the use of stress and fear in instruction. AMA Journal of Ethics, 16(3), 182-186.

Zou, L, King, A., Soman, S., Lischuk, A, Schneider, B. Walor, D., Amorosa, J. K. (2011). Medical students' preferences in radiology education: a comparison between the Socratic and didactic methods utilizing PowerPoint features in radiology education. Academic radiology, 18(2), 253-256. 